\title{
GLOSA DO WYROKU WSA W KRAKOWIE Z DNIA 3 GRUDNIA 2013 R., II SA/KR 1098/13
}

\section{COMMENTARY TO THE JUDGMENT OF THE VOIVODESHIP ADMINISTRATIVE COURT IN KRAKÓW OF 3 DECEMBER 2013, II SA/KR 1098/1013}

\section{STRESZCZENIE}

Interes społeczny jest kategorią pojęcia niedookreślonego. Dlatego też pojęcie to należy interpretować szeroko. W postępowaniu administracyjnym interes publiczny jest reprezentowany przez organizacje społeczne, które reprezentują interesy innych podmiotów. W związku $\mathrm{z}$ tym $\mathrm{w}$ postępowaniach administracyjnych powinny uczestniczyć organizacje ze względu na interes społeczny nie tylko danej organizacji,

* Doktor nauk prawnych, radca prawny, adiunkt EWSPA w Warszawie. 
ale również innych podmiotów. Efektem rozważań autorki nad orzeczeniem sądu jest stwierdzenie, że walory krajobrazowe mogą być elementem chronionego interesu społecznego.

\section{Słowa kluczowe}

Interes społeczny; walory krajobrazowe.

\section{ABSTRACT}

The concept of public interest is vague. Therefore, this concept should be interpreted widely. In administrative proceedings public interest is supported by public organizations, which represent the interest of other entities. Public organization involvement depends on the kind of interest they act for. The result of the author's reflections on the decision of the court is that landscapes can be part of protected public interest and they should be supported by public organizations.

Keywords

Public interest; landscapes.

Sprawy inwestycyjne, których przedmiotem jest budowa obiektów wpływających znacząco na środowisko, są często przedmiotem wyrokowania sądów administracyjnych. Istotne znaczenie dla środowiska w szerokim tego pojęcia znaczeniu mają sprawy związane z oddziaływaniem inwestycji na kształtowanie krajobrazu oraz kształtowanie systemu przyrodniczego.

Z działalnością na rzecz środowiska związane są liczne organizacje stawiające sobie za cel swego rodzaju kontrolę nad sposobem kształtowania obszarów o znaczeniu krajobrazowym, kulturowym czy środowiskowym.

Stąd wiele jest spraw na poziomie organów administracji publicznej, w których organy muszą dokonać stosownej oceny w zakresie dopuszczenia do udziału w postępowaniu podmiotu zajmującego się szeroko pojętą ochroną środowiska, ale także 
jego poszczególnych składników. Tego rodzaju sprawy mają doniosłe znaczenie społeczne, jako że dotyczą dóbr o charakterze publicznym.

II.

Glosowane orzeczenie dotyczyło skargi „Towarzystwa [...] w K. na postanowienie Samorządowego Kolegium Odwoławczego w K. z dnia 14 czerwca 2013 r. znak: [...] w przedmiocie odmowy dopuszczenia do udziału w sprawie". WSA w Krakowie wyrokiem z dnia 3 grudnia 2013 r. uchylił zaskarżone postanowienie oraz poprzedzające je postanowienie organu I instancji.

W sprawie zakończonej wyrokiem sądu „Towarzystwo [...] w K. powołując się na cele swej działalności wynikające ze Statutu, zwróciło się o dopuszczenie do udziału w postępowaniu sprawie ustalenia warunków zabudowy dla inwestycji pn. „Budowa budynku mieszkalnego jednorodzinnego $\mathrm{z}$ instalacjami wewnętrznymi na działce $\mathrm{nr}$ [....] obr. [...] w K. wraz z budową zjazdu z działki drogowej nr [...] obr. [...] oraz infrastrukturą techniczną, w rejonie ul. [...] w $\mathrm{K}$.

Prezydent Miasta K. postanowieniem z dnia 8 maja 2013 r. odmówił dopuszczenia Towarzystwa [...] w K. do udziału w postępowaniu na podstawie art. 33 § 1 i 2 K.p.a. w związku z art. 123 K.p.a.

W uzasadnieniu przywołano podstawę prawną, wyjaśniono pojęcie interesu społecznego i stwierdzono, że nie przemawia on za dopuszczeniem wnioskodawcy do udziału w postępowaniu. Podniesiono, że skala i program inwestycji, dla której jest prowadzone postępowanie, nie przemawia za uznaniem, że przedmiotowa budowa wpłynie w istotny sposób na sylwetkę miasta, kształtowanie krajobrazu, czy kształtowanie systemu przyrodniczego. Wskazano, że teren objęty przedmiotowym wnioskiem znajduje się w bezpośrednim sąsiedztwie zabudowy mieszkalnej jednorodzinnej. Podkreślono ponadto, że Towarzystwo [...] nie wskazało na czym będzie polegać - w tej konkretnej sprawie - jego działanie w interesie społecznym. 
Zażalenie na powyższe postanowienie w ustawowym terminie złożyło Towarzystwo [...] w K. reprezentowane przez Prezesa M.W. W uzasadnieniu podniesiono, że za dopuszczeniem Towarzystwa do udziału w postępowaniu przemawiają zarówno cele działalności organizacji i interes społeczny, co zostało wykazane we wniosku między innymi o uwarunkowania środowiskowe, położenie w strefie zagrożenia powodziowego. Błędne jest stwierdzenie, przed wysłuchaniem argumentów organizacji zainteresowanej sprawą, że budowa nie wpłynie w istotny sposób na sylwetę miasta, kształtowanie krajobrazu, czy kształtowanie systemu przyrodniczego. Zwrócono uwagę, ze próba odsunięcia Towarzystwa [...] w K. od udziału w postępowaniu stanowi próbę powstrzymania społecznej kontroli rzetelności prowadzenia postępowania, a w interesie społecznym jest prowadzenie społecznej kontroli postępowań. Podkreślono, że Towarzystwo zgłosiło wniosek o dopuszczenie do udziału w postępowaniu, ponieważ ochrona przyrody, środowiska, krajobrazu, a także wyeliminowanie ponoszenia przez społeczeństwa kosztów prowadzenia akcji ratunkowych, likwidacji szkód powodziowych i wspierania finansowego ofiar powodzi w związku $\mathrm{z}$ realizacją inwestycji w obszarze zagrożenia powodziowego leży w interesie społecznym. Zwrócono również uwagę, że w niniejszej sprawie nie trudno nie zauważyć, że cele statutowe Towarzystwa pozostają w bardzo ścisłym związku z przedmiotem postępowania, co wskazywałoby, że istnieje także interes społeczny. Skoro organizacja społeczna została powołana, aby chronić środowisko, wartości kulturowe, to interes społeczny przemawia właśnie za tym, aby mogła ta organizacja uczestniczyć w postępowaniach, które mogą doprowadzić do negatywnych skutków w środowisku przyrodniczym.

Samorządowe Kolegium Odwoławcze w K. postanowieniem z dnia 14 czerwca 2013 r. znak:[...], działając na podstawie art. $31 \S 1$ pkt 2 i $\S 2$ K.p.a. w związku z art. $138 \S 1$ pkt 1 K.p.a., utrzymało w mocy zaskarżone postanowienie organu I instancji.

W uzasadnieniu podano, że zgodnie z przepisem art. $31 \S 1$ pkt 2 K.p.a. organizacja społeczna może w sprawie dotyczącej 3/2014 innej osoby występować z żądaniem dopuszczenia jej do udzia- 
łu w postępowaniu, jeżeli jest to uzasadnione celami statutowymi tej organizacji i przemawia za tym interes społeczny. Przed organem I instancji prowadzone jest postępowanie w sprawie ustalenia warunków zabudowy dla inwestycji pn. „Budowa budynku mieszkalnego jednorodzinnego z instalacjami wewnętrznymi na działce nr [...] obr. 1 [... ] w K. wraz z budową zjazdu z działki drogowej nr [...] Obr[...] oraz infrastrukturą techniczną, w rejonie ul. [...] w K.".

Ze znajdującego się w aktach sprawy Statutu Towarzystwa wynika, że jego głównym celem, między innymi, jest niewątpliwie ochrona przyrody oraz ochrona środowiska, a cele te są realizowane, również między innymi, poprzez podejmowanie działań interwencyjnych na rzecz ochrony przyrody.

W związku z powyższym stwierdzono, że wskazane w Statucie cele Towarzystwa mogą, co do samej zasady, uzasadniać jego udział w określonych postępowaniach administracyjnych, to jednak nie oznacza to, że Towarzystwo, niejako automatycznie, winno być dopuszczone do udziału w każdym postępowaniu w sprawie ustalenia warunków zabudowy, do którego zgłosi wolę przystąpienia. Jak podkreślił Wojewódzki Sąd Administracyjny w Warszawie w wyroku z dnia 20 lipca 2010 r. sygn. akt IV SA/Wa 847/10 - pojęcie „interesu społecznego” nie zostało określone $\mathrm{w}$ przepisach prawa [...]. W rezultacie ocena wystąpienia przesłanki interesu społecznego w dopuszczeniu organizacji społecznej do udziału w postępowaniu należy do organu administracji. Organizacja społeczna powinna zatem wykazać zasadność udziału w postępowaniu, ponieważ jej udział w sprawie nie jest obojętny dla stron, zwłaszcza gdy reprezentują przeciwstawne interesy. Organizacja powinna też wykazać, jakie posiada „kwalifikacje” do występowania w danej konkretnej sprawie. Musi istnieć merytoryczne powiązanie między przedmiotem sprawy a osiągnięciami, specjalizacja działania, a nie tylko celami organizacji społecznej. Kolegium podniosło, że w niniejszej sprawie oprócz wykazania zainteresowania jej przedmiotem, Towarzystwo żadnej z tych okoliczności nie wykazało. Powołanie się na cele statutowe jest niewystarczające, gdy chce się brać udział w tak specjalistycznym postępowaniu, jakim jest postępowanie o ustalenie warunków zabudowy, 
w którym rozstrzyga się skomplikowane kwestie z bardzo wielu szczegółowych dziedzin prawa administracyjnego (w jego szerokim znaczeniu).

Kolegium podzieliło pogląd sformułowany w zaskarżonym postanowieniu, że skala i program inwestycji, dla której jest prowadzone postępowanie nie przemawia za uznaniem, że przedmiotowa budowa wpłynie $\mathrm{w}$ istotny sposób na sylwetę miasta, kształtowanie krajobrazu, czy kształtowanie systemu przyrodniczego. Stąd trudno również przyjąć, że planowana inwestycja (budowa budynku mieszkalnego jednorodzinnego z instalacjami wewnętrznymi) ze względu na jej rodzaj, będzie ingerować $\mathrm{w}$ znacznym, ponadprzeciętnym stopniu w stan środowiska oraz funkcjonowanie społeczności lokalnej, a zatem wzgląd na interes społeczny uzasadniałby dopuszczenie organizacji społecznej do udziału w postępowaniu w sprawie ustalenia warunków zabudowy. Powyższe stanowisko potwierdza również pogląd prezentowany w orzecznictwie sądów administracyjnych: jedynie faktyczne i prawne powiązanie celów statutowych organizacji z meritum postępowania administracyjnego, którego domaga się ona wszczęcia, może powodować zastosowanie art. $31 \S 1$ pkt 1 K.p.a. (wyrok Wojewódzkiego Sądu Administracyjnego w Gliwicach z dnia 31 lipca 2008 r., sygn. akt II SA/G1 198/08, opub. w Lex nr 510179); stowarzyszenie dla uzasadnienia swego wniosku powinno przedłożyć dowody wskazujące, że inwestycja stwarza zagrożenie dla środowiska, co pozwoliłoby na przyjęcie, że istnieje interes prawny przemawiający za wszczęciem postępowania zgodnie z wnioskiem stowarzyszenia (wyrok Wojewódzkiego Sądu Administracyjnego w Warszawie z dnia 6 października 2008 r., sygn. akt VII SA/Wa 996/08, opub. w Lex nr 533185); przesłanki udziału organizacji społecznych w postępowaniu nie mogą być interpretowane rozszerzająca. O ile celem konkretnego stowarzyszenia jest ochrona określonych walorów architektonicznych, walory te muszą być wstępnie wykazane (wyrok Wojewódzkiego Sądu Administracyjnego w Warszawie z dnia 24 czerwca 2008 r., sygn. akt IV SA/Wa 740/08, opub. w Lex nr 516100).

Kolegium Odwoławcze nawiązało także do stanowiska 3/2014 sformułowanego w wyroku Naczelnego Sądu Administracyj- 
nego z dnia 14 marca 2013 r., sygn. akt II OSK 2536/10. Sąd zwrócił uwagę, że wymóg łącznego spełnienia przesłanek ma również duże znaczenie dla układu podmiotowego postępowania przez wyłączenie rozszerzenia jego kręgu uczestników na podmioty nie mające interesu prawnego, a legitymujące się jedynie interesem faktycznym (B. Adamiak, Glosa do postanowienia Naczelnego Sądu Administracyjnego z dnia 28 września 2009 r. sygn. akt II GZ 55/09, OSP z 2011 r., z. 11, poz. 108). Zauważono, że pojęcie „interesu społecznego” wymaga każdorazowo indywidualnej oceny. Nadto koniecznym jest podkreślenie, że przy ustaleniu spełnienia przesłanek warunkujących dopuszczenie organizacji społecznej do udziału w postępowaniu administracyjnym dotyczącym praw lub obowiązków osób trzecich nie jest dopuszczalna wykładnia rozszerzająca, albowiem dopuszczenie innego podmiotu, który nie broni własnego interesu prawnego zmienia układ praw procesowych strony, przyznając te prawa także innemu podmiotowi (wyrok Naczelnego Sądu Administracyjnego z dnia 2 czerwca 2009 r., sygn. akt II OSK 897/08, opub. w Lex nr 549644).

Organizacja społeczna ubiegająca się o dopuszczenie jej do udziału w postępowaniu winna uprawdopodobnić, że przyczyni się do lepszego wypełnienia przez postępowanie administracyjne jego celów (wyrok Naczelnego Sądu Administracyjnego z 24 czerwca 2009 r., sygn. akt II OSK 1038/08). Natomiast na organie administracji spoczywa cały ciężar zweryfikowania zasadności bądź niezasadności dopuszczenia organizacji społecznej (wyrok Naczelnego Sądu Administracyjnego z dnia 23 września 2009 r., sygn. akt II OSK 1339/09).

W okolicznościach rozpatrywanej sprawy poza sporem pozostawało, że udział Stowarzyszenia w toczącym się postępowaniu o wydanie decyzji o warunkach zabudowy jest uzasadniony jego celami statutowymi. Kwestionowana była zaś okoliczność istnienia interesu społecznego uzasadniającego dopuszczenie tego Stowarzyszenia do udziału w postępowaniu. Rozstrzyganie kwestii dopuszczalności udziału organizacji społecznej w postępowaniu administracyjnym, dotyczącym innej osoby, musi być połączone z rozważeniem, czy za tym udziałem przemawia interes społeczny. Wniosek o dopuszcze- 
nie do tego udziału musi by zatem poparty stosownymi argumentami [...].

Podniesiono, że wnioskodawca spełnił wymogi określone w art. $31 \S 1$ K.p.a. natomiast Prezydent Miasta K. przekroczył swoje uprawnienia dokonując dowolnie interpretacji sformułowań „cele statutowe organizacji” i „interes społeczny”. Nieprawdziwe jest stwierdzenie wydającego postanowienie, że wnioskodawca nie wskazał jaki społeczny przemawia za włączeniem Towarzystwa do udziału w postępowaniu.

W ocenie skarżącego, za dopuszczeniem Towarzystwa do udziału w przedmiotowym postępowaniu przemawiają cele działalności organizacji jak i interes społeczny, co zostało wykazane we wniosku, miedzy innymi, uwarunkowania środowiskowe (teren inwestycji położony jest w obrębie obszaru o wysokich walorach krajobrazowych, na terenie [...] Parku Krajobrazowego, w ochrony i kształtowania krajobrazu oraz strefie kształtowania systemu przyrodniczego określonych w Studium uwarunkowań i kierunków zagospodarowania przestrzennego K.), położenie w strefie zagrożenia powodziowego (ponoszenie przez społeczeństwo kosztów prowadzenia akcji ratunkowych, likwidacji szkód powodziowych i wspieranie finansowe ofiar powodzi). Błędne jest stwierdzenie, przed wysłuchaniem argumentów organizacji zainteresowanej sprawą, że budowa nie wpłynie w istotny sposób na sylwetę miasta, kształtowanie krajobrazu czy kształtowanie systemu przyrodniczego.

Organ nie odniósł się do wskazanego we wniosku uzasadnienia dopuszczenia do udziału w postępowaniu administracyjnym $[\ldots]$.

Samorządowemu Kolegium Odwoławczemu w K. zarzucono nieustosunkowanie się do zarzutów podniesionych w zażaleniu, pominięcie argumentów zawartych zarówno we wniosku Towarzystwa [...], jak i w zażaleniu na postanowienie organu I instancji, błędną i samowolną interpretację sformułowania „interes społeczny”.

Towarzystwo podniosło, że „interes społeczny” nie jest ustawowo zdefiniowany co powoduje że treść nadaje mu orzekający, lecz zgodnie z wyrokiem Naczelnego Sądu Admini3/2014 stracyjnego z dnia 27 stycznia 2011 r., sygn. akt I OSK 11/09, 
zgodnie z którym „działanie w uznania administracyjnego nie oznacza dowolności organów przy wydawaniu decyzji, organy wykazać, że w konkretnej sprawie istniały przesłanki uzasadniające podjęte rozstrzygnięcie".

Wskazano, że w interesie publicznym jest działalność na rzecz zachowania wartości przyrodniczych poszanowania prawa oraz udział obywateli w procesach decyzyjnych. Podjęte przez Towarzystwo działania w zakresie inwestycji mają na celu dbałość o dobro wspólne - przyrodę i egzekwowanie prawa.

Podniesiono również zarzut nieustosunkowania się do argumentu położenia inwestycji w strefie zagrożenia powodziowego.

W odpowiedzi na skargę Samorządowe Kolegium Odwoławcze w K. wniosło o jej oddalenie w całości podtrzymując swoje stanowisko zawarte $\mathrm{w}$ uzasadnieniu zakwestionowanego postanowienia.

Wojewódzki Sąd Administracyjny w Krakowie, zważył, co następuje [...]:

Towarzystwo [...] posiada $\mathrm{w}$ tej sprawie legitymację do wniesienia skargi na podstawie art. 50 § 1 P.p.s.a. Zgodnie z tym przepisem organizacja społeczna może wnieść skargę, jeżeli dana sprawa objęta jest zakresem jej statutowej działalności, sprawa dotyczy interesów prawnych innych osób i brała ona udział w postępowaniu administracyjnym. Objęta skargą Towarzystwa [...] (dalej w skrócie jako „Towarzystwo”) sprawa dotyczy jedynie postępowania administracyjnego obejmującego odmowę dopuszczenia Towarzystwa do udziału w postępowaniu w przedmiocie ustalenia warunków zabudowy dla inwestycji pn. „budowa budynku mieszkalnego jednorodzinnego z instalacjami wewnętrznymi na działce $\mathrm{nr}[\ldots]$ Obr [...] j w K. wraz $\mathrm{z}$ budową zjazdu z działki drogowej nr [...] obr. [...] oraz infrastrukturą techniczną, w rejonie ul. [...] w K". Towarzystwo brało udział w postępowaniu dotyczącym dopuszczenia go do udziału w sprawie ustalenia warunków zabudowy, dopuszczenie lub odmowa dopuszczenia do udziału w tej sprawie dotyczy interesów prawnych innych osób (stron). Także spełniona została przesłanka polegająca na istnieniu związku pomiędzy sprawą dotyczącą odmowy dopuszczenia do udziału w postępowaniu a zakresu 
statutowej działalności Towarzystwa. Co do zasady w każdym bowiem przypadku, gdy skargę na postanowienie o odmowie dopuszczenia organizacji społecznej wnosi taka organizacja, ma to związek z zakresem działalności statutowej. To ustalenie dotyczy tylko skargi na postanowienie $\mathrm{w}$ przedmiocie odmowy dopuszczenia do udziału w postępowaniu danej organizacji społecznej i nie może przesądzać o legitymacji procesowej do ewentualnego wniesienia skargi na decyzję merytoryczną rozstrzygającą sprawę administracyjną. NSA w postanowieniu z dnia 15 stycznia 2013 r., sygn. akt II OSK 3073/12, opub. w Lex nr 1274424, wyraźnie stwierdził, że na postanowienie o odmowie wszczęcia postępowania lub dopuszczenia do udziału w postępowaniu zażalenie służy tylko organizacji społecznej, a skargę do sądu administracyjnego może wnieść organizacja społeczna, jeżeli po wyczerpaniu środka zaskarżenia jej żądanie nadal nie będzie uwzględnione, tj. nie będzie ona dopuszczona do udziału w postępowaniu administracyjnym.

Po ustaleniu, że w tej sprawie Towarzystwo miało legitymację do wniesienia skargi, Sąd przystępuje do rozpoznania meritum sprawy.

Istota rozpoznawanej sprawy dotyczy prawidłowości rozstrzygnięcia przez organy administracyjne odmawiające wszczęcia $\mathrm{w}$ tej sprawie postępowania administracyjnego na wniosek skarżącej organizacji społecznej, wniesiony na podstawie art. $31 \S 1$ pkt 1 i 2 K.p.a.

Jak wynika z akt sprawy, wnioskiem z daty 23 kwietnia 2013 r. (akta administracyjne, karta nr [...]) Towarzystwo zwróciło się o dopuszczenie go do udziału w sprawie powołując się na swój cel statutowy, jakim jest ochrona przyrody, ochrona środowiska, ochrona krajobrazu. Wskazała, że teren inwestycji jest obszarem o wysokich walorach krajobrazowych, objęty [...] Parkiem Krajobrazowym, położonym w obszarze objętym w Studium uwarunkowań i kierunków zagospodarowania przestrzennego Miasta K. strefą ochrony i kształtowania krajobrazu i strefą kształtowania systemu przyrodniczego. Teren inwestycji położony jest także w pobliżu chronionego prawem starorzecza W. i w obszarze zagrożenia powodziowego. Towarzystwo 3/2014 wskazało także na interes społeczny uzasadniający jego udział 
$\mathrm{w}$ tym postępowaniu. Jako uzasadnienie interesu społecznego Towarzystwo wskazało na wpływ wydanej decyzji ustalającej warunki zabudowy na krajobraz i przyrodę w obrębie obszaru o wysokich walorach krajobrazowych, objętego parkiem krajobrazowych, strefami ochrony zawartymi w studium i obszarem starorzecza. W interesie społecznym jest wyeliminowanie podejrzeń wydających decyzje o działania stronnicze. Towarzystwo podniosło również, że $\mathrm{w}$ interesie społecznym jest także niedopuszczenie do nieodwracalnych zmian w otoczeniu poprzez nieprawidłowe zabudowanie tego obszaru na podstawie warunków zabudowy oraz $\mathrm{w}$ interesie społecznym jest niedopuszczenie do ponoszenia kosztów prowadzonych akcji ratunkowych, likwidacji szkód powodziowych i wspierania finansowego ofiar powodzi.

W zażaleniu na postanowienie odmawiające dopuszczenia do udziału w sprawie Towarzystwo dodatkowo wskazało na ochronę przed podejrzeniem o korupcyjne działania pracowników organu I instancji, a także o ograniczanie społecznej kontroli prawidłowości prowadzonego postępowania (akta administracyjne, karty $\mathrm{nr}[\ldots]$.

Odmowa wszczęcia postępowania nastąpiła na podstawie art. $31 \S 1$ pkt 1 K.p.a., zgodnie z którym organizacja społeczna może w sprawie dotyczącej innej osoby występować z żądaniem dopuszczenia do udziału w postępowaniu lub wszczęcia postępowania administracyjnego, jeżeli jest to uzasadnione celami statutowymi tej organizacji i gdy przemawia za tym interes społeczny.

Stosownie do art. $31 \S 1$ pkt 2 k.p.a. organizacja społeczna w sprawie dotyczącej innej osoby może domagać się uczestniczenia $\mathrm{w}$ postępowaniu, jeżeli jest to uzasadnione celami statutowymi tej organizacji i gdy przemawia za tym interes społeczny. Ustalenie, czy zakres działalności statutowej danej organizacji uzasadnia dopuszczenie do udziału w postępowaniu powinno sprowadzać się do porównania zakresu tej działalności z przedmiotem danej sprawy. Każdy cel działania określony w statucie nadanym, czy przyjętym zgodnie z obowiązującym prawem może uzasadniać wystąpienie z żądaniem dopuszczenia do udziału w postępowaniu, jeżeli przedmiot 
postępowania wkracza w zakres działań organizacji społecznej, czy to ze względu na czynności postępowania, czy też ze względu na jego wynik.

Zgodnie z art. $31 \S 1$ pkt 2 K.p.a. Stowarzyszenie jako organizacja społeczna może domagać się dopuszczenia do udziału $\mathrm{w}$ postępowaniu administracyjnym $\mathrm{w}$ razie łącznego spełnienia się dwóch odrębnych przesłanek:

1) wniosek o dopuszczenie do udziału byłoby uzasadniony celami statutowymi,

2) za takim dopuszczeniem przemawiałby interes społeczny.

W ocenie Sądu pierwsza z ww. przesłanek jest spełniona. Nie ulega wątpliwości, że postępowanie zmierzające do ustalenia warunków zabudowy dla zamierzenia inwestycyjnego na działce nr [...] w K. znajduje się w obszarze [...] Parku Krajobrazowego. Także w zdecydowanej większości działka nr [...] znajduje się w odległości mniejszej niż 100 metrów od krawędzi skarpy starorzecza W. (akta administracyjne, karty nr [...]).

Tym samym pozostawanie terenu objętego wnioskiem o ustalenie warunków zabudowy w obszarze objętym formą ochrony przyrody (park krajobrazowy) oznacza, że organizacja społeczna, której celem jest ochrona przyrody, spełnia warunek wynikający z zasadności udziału $\mathrm{w}$ takim postępowaniu w związku z jej celami statutowymi. Istnieje niewątpliwie związek pomiędzy zapewnieniem ochrony przyrody a obszarem, na którym cele ochrony przyrody zostały uznane za istotne.

Należy także rozważyć i drogą przesłankę dopuszczenia organizacji społecznej do udziału w postępowaniu, jaką jest przemawianie za takim dopuszczeniem interesu społecznego.

Naczelny Sąd Administracyjny w wyroku z dnia 19 lipca 2012 r., sygn. akt II OSK 663/11, opub. w Lex nr 1217445 stwierdził, że nie jest dopuszczalna taka wykładnia art. $31 \S 1$ k.p.a., zgodnie z którą organ administracji publicznej byłby niejako automatycznie zobligowany do uwzględnienia żądania organizacji społecznej z tych tylko powodów, że jest ona formalnie organizacją społeczną, której żądanie jest uzasadnione celami statutowymi, bez badania czy przemawia za tym interes spo3/2014 łeczny. 
Ocena wystąpienia interesu społecznego musi być przedmiotem tak badania organów administracji w zakresie dopuszczenia organizacji społecznej do udziału w postępowaniu, jak również sama organizacja musi wykazać wystąpienie tej przesłanki. Naczelny Sąd Administracyjny w wyroku z dnia 11 kwietnia 2012 r., sygn. akt II OSK 122/11, opub. w Lex nr 1251768 wskazał, że organizacja społeczna, której celami statutowymi jest szeroko rozumiana ochrona środowiska lub przyrody, jak również działania proekologiczne i która zgłasza swój udział w postępowaniu dotyczącym orzeczeń wydawanych nie na podstawie przepisów ustawy z 2008 r. o udostępnieniu informacji o środowisku, wykazując, iż za jej udziałem w postępowaniu na podstawie art. $31 \S 1$ pkt 2 k.p.a. przemawia interes społeczny ma obowiązek przedstawić szczególną argumentację w tym zakresie i udział takiej organizacji społecznej w wyżej wymienionych postępowaniach powinien być rozważany w wyjątkowych przypadkach ponieważ istnieje ustawa szczególna, która te kwestie rozwiązuje w sposób zapewniający odpowiedni udział społeczeństwa $\mathrm{w}$ procesie inwestycyjnym.

Sąd w tym składzie w pełni aprobuje ten pogląd. Nie ma stałego wzorca ani reguły, jak powinna organizacja społeczna wykazać organowi administracji publicznej, do którego skierowała żądanie, że za jej udziałem w postępowaniu na prawach strony przemawia interes społeczny. W każdym przypadku należy tę kwestię rozpatrywać indywidualnie. Niewątpliwie pojęcie interesu społecznego nie może być traktowane jako synonim celu statutowego organizacji społecznej. Podnoszone przez Towarzystwo argumenty dotyczące wpływu decyzji ustalającej warunki zabudowy na krajobraz i przyrodę w obszarze o wysokich walorach krajobrazowych nie stanowią w tej sprawie celu społecznego. Wpływ wydanej decyzji ustalającej warunki zabudowy na środowisko i przyrodę spełnia przesłankę celu statutowego Towarzystwa, o czym była mowa wyżej. O ile ochrona przyrody w obszarze objętym parkiem krajobrazowym uzasadniałaby uznanie za dopuszczalnością dopuszczenia do udziału z powodu celów statutowych organizacji społecznej, to nie stanowi to automatycznie spełnienia przesłanki „przemawiania” za takim dopuszczenie interesu społecznego. 
Jako interes społeczny Towarzystwo wskazało:

a) eliminowanie podejrzeń o stronniczość lub korupcję wśród pracowników organu I instancji;

b) niedopuszczenie do spowodowania nieodwracalnych zmian w otoczeniu poprzez nieprawidłowe zabudowanie tego obszaru na podstawie warunków zabudowy;

c) niedopuszczalność ponoszenia kosztów prowadzonych akcji ratunkowych, likwidacji szkód powodziowych i wspierania finansowego ofiar powodzi, skoro istnieje możliwość zalania obszaru objętego w tej sprawie wnioskiem przez inwestora.

W ocenie Sądu część z ww. przesłanek uzasadnia uznanie, że $\mathrm{w}$ tej sprawie zaistniała także przesłanka „przemawiania” za udziałem w postępowaniu Towarzystwa interesu społecznego. Podnoszone okoliczności mają znaczenie społeczne. Interes społeczny winien nawiązywać do racjonalnie pojmowanej kontroli społecznej obejmującej sprawy indywidualne (wyrok Wojewódzkiego Sądu Administracyjnego w Krakowie z dnia 13 kwietnia 2012 r., sygn. akt II SA/Kr 151/12, opub. w Lex nr 1145792).

Towarzystwo wyraźnie akcentuje potrzebę zapewnienia przejrzystości (transparentności) prowadzonego postępowania administracyjnego, ale taki argument mógłby być podnoszony w każdym postępowaniu administracyjnym. W żadnym zakresie Towarzystwo nie wykazało, żeby w tej konkretnej sprawie zaistniały jakiekolwiek okoliczności wskazujące, chociażby pośrednio, na potrzebę zapewnienia przejrzystości stosowania procedury administracyjnej lub potrzebę zabezpieczenia przed jakimikolwiek zjawiskami korupcjogennymi. Powołanie tej przesłanki nie uzasadnia jej jako ochrony interesu społecznego przemawiającego za dopuszczeniem do udziału w postępowaniu Towarzystwa.

Druga z wyżej podniesionych przesłanek, jaką jest niedopuszczenie do spowodowania nieodwracalnych zmian w otoczeniu poprzez nieprawidłowe zabudowanie tego obszaru na podstawie warunków zabudowy, także nie została przez Towarzystwo wykazana w kontekście ochrony interesu społecznego. 3/2014 Towarzystwo w żadnym zakresie nie wykazało, że ustalenie 
warunków zabudowy będzie skutkowało nieprawidłowym zabudowaniem danego terenu i takie nieprawidłowe zabudowanie terenu naruszy interes społeczny. W szczególności brak jest chociażby częściowego wykazania, że ustalone warunki zabudowy nie są akceptowalne $\mathrm{z}$ powodu interesu społecznego lub też w jakim zakresie ten interes społeczny byłby naruszony. Brakuje także argumentów powołanych przez Towarzystwo, które by wyraźnie odnosiły się do interesów określonej grupy osób, społeczności lokalnej lub innej wspólnoty. Interes społeczny nie jest pojęciem abstrakcyjnym, ale musi odnosić się do określonej grupy społecznej, społeczności lokalnej lub większej wspólnoty, która byłaby zainteresowana określonym działaniem.

Natomiast trzecia $\mathrm{z}$ podniesionych przesłanek może być uznana za spełniająca wymogi zachowania interesu społecznego.

Jak wynika ze znajdujących się w sprawie pism $\mathrm{z}$ daty 7 grudnia 2012 r. i 28 listopada 2012 r. (akta administracyjne, karty $\mathrm{nr}[\ldots])$, teren objętym zamierzeniem inwestycyjnym znajduje się w obszarze zagrożenia powodziowego i w obszarze lokalnym podtopień. Dwa wydziały Urzędu Miasta K. (Wydział Kształtowania Środowiska i Wydział Bezpieczeństwa i Zarządzania Kryzysowego) zajęły negatywne stanowiska co do możliwości ustalania warunków zabudowy na tym obszarze właśnie z powodu zagrożenia powodziowego. Po modyfikacji wniosku, Wydział Kształtowania Środowiska pismem z dnia 12 lutego 2013 r. wyraził pozytywne stanowisko (akta administracyjne, karty nr [...].

Niewątpliwie przesłanka polegająca na niedopuszczalności ponoszenia kosztów prowadzonych akcji ratunkowych, likwidacji szkód powodziowych i wspierania finansowego ofiar powodzi, w związku z wybudowaniem budynku na terenie zagrożonym powodzią wymaga szczegółowego ustosunkowania się. Sąd wprawdzie nie przychyla się do argumentacji, jakoby niedopuszczalnym z puntu widzenia społeczeństwa byłoby ponoszenie kosztów akcji ratunkowych związanych z ratowaniem osób z terenów powodziowych, czy też niedopuszczalnością byłoby wspieranie finansowe ofiar powodzi, to jednak tak zarysowana przesłanka spełnia w tej sprawie przesłankę uzasadniającą dopuszczenie Towarzystwa do udziału w tej sprawie, za któ- 
rym przemawia interes społeczny. W interesie społecznym jest takie ustalanie warunków zabudowy, aby określać te warunki z uwzględnieniem takich czynników naturalnych jak np. zagrożenie powodzią, trzęsieniami ziemi, innymi zjawiskami atmosferycznymi lub tektonicznymi, mogącymi wywoływać istotne skutki społeczne. Zjawiska takie jak powódź dotykają z reguły społeczności, a nie tylko pojedyncze osoby i nawet w przypadku ustalania warunków zabudowy na terenie zagrożonym powodzią, ma to związek z interesem społeczności.

Tym samym okoliczność, że obszar objęty wnioskiem o ustalenie warunków zabudowy obejmuje teren zagrożony powodziami uzasadnia w tej sprawie dopuszczenie do takiego postępowania organizacji społecznej wskazującej za przemawianiem za tym interesu społecznego.

Sąd ma na uwadze i tą okoliczność, że organizacja społeczna nie może, w związku z art. 28 ust. 3 Prawa budowlanego, skutecznie brać udziału w postępowaniu w przedmiocie udzielenia pozwolenia na budowę. Zamierzona inwestycja polegająca na budowie domu mieszkalnego jednorodzinnego nie jest zaliczania do inwestycji mogących zawsze znacząco oddziaływać na środowisko lub potencjalnie znacząco oddziaływać na środowisko, co znacząco ogranicza także udział organizacji ekologicznych lub społeczeństwa w postępowaniu opartym o przepisy ustawy z dnia 3 października 2008 r. o udostępnianiu informacji o środowisku i jego ochronie, udziale społeczeństwa w ochronie środowiska oraz o ocenach oddziaływania na środowisko (Dz. U. Nr 199, poz. 1227 z późn. zm.).

Mając powyższe na uwadze, należało stwierdzić, że w tej sprawie w ocenie Sądu zostały spełnione przesłanki wynikające z art. 31 ust. 1 K.p.a. i przemawiające za dopuszczeniem do udziału w postępowaniu skarżącego Towarzystwa.

Sąd natomiast nie podziela argumentacji Samorządowego Kolegium Odwoławczego w K. Nie wynika bowiem żadnej podstawy prawnej do domagania się od organizacji społecznej wykazywania się jakimiś szczególnymi kwalifikacjami do występowania w konkretnej sprawie, a tym bardziej wykazania przez organizację, że istnieją merytoryczne powiązania 3/2014 pomiędzy przedmiotem sprawy a osiągnięciami, specjalnością 
działania. Kolegium Odwoławcze podniosło, że same cele statutowe nie mogą uzasadniać dopuszczenia danej organizacji do udziału $\mathrm{w}$ postępowaniu, które ma charakter postępowania specjalistycznego, rozstrzygającego kwestie z bardzo wielu szczegółowych dziedzin prawa administracyjnego. Przyjęcie takiego poglądu skutkowałoby daleko idącym ograniczeniem takich organizacji w postępowaniach administracyjnych i nie ma wyraźnej podstawy w treści art. 31 K.p.a. Zapewne Kolegium chodziło w jakąś formę racjonalnego dopuszczania organizacji społecznych do udziału w postępowaniach administracyjnych, ale nie może to prowadzić do określania nieznanych ustawodawcy przesłanek typu: specjalizacja działania i to niezależnie od celów statutowych, dotychczasowe osiągnięcia lub stopień skomplikowania sprawy.

Mając powyższe na uwadze, Sąd uznał, że w tej sprawie organy administracji naruszyły art. $31 \S 1$ pkt 2 K.p.a. w stopniu mogącym mieć istotny wpływ na wynik sprawy. Tym samy oba wydane postanowienia podlegają - zgodnie z art. $145 \S 1$ pkt 1 lit. c P.p.s.a. - uchyleniu.

Zgodnie z art. 141 § 4 P.p.s.a. ponownie rozpoznając wniosek Towarzystwa organ I instancji winien dopuścić to Towarzystwo do udziału w sprawie, chyba że zmianie uległ stan faktyczny lub prawny sprawy, uzasadniający przyjęcie odmiennego stanowiska.

III.

W sprawie będącej przedmiotem omawianego orzeczenia w pierwszej kolejności należało szczegółowo zająć się pojęciem interesu społecznego.

Natomiast drugą kwestią wartą rozważenia jest problem postrzegania nieodwracalnych zmian $\mathrm{w}$ otoczeniu, $\mathrm{w}$ tym w krajobrazie, jako działań mieszczących się w ramach pojęcia interesu społecznego.

Interes społeczny jest kategorią pojęcia niedookreślonego. Należy ujmować go szeroko. W związku z tym w postępowa- 
niach administracyjnych powinny uczestniczyć organizacje ze względu na interes społeczny nie tylko danej organizacji, ale większej liczby podmiotów. Ustawodawca wyraźnie zaznaczył w art. $31 \S 1$ ustawy z dnia 14 czerwca 1960 r. Kodeks postępowania administracyjnego ${ }^{1}$, że „Organizacja społeczna może w sprawie dotyczącej innej osoby występować z żądaniem:

1) wszczęcia postępowania,

2) dopuszczenia jej do udziału w postępowaniu,

jeżeli jest to uzasadnione celami statutowymi tej organizacji i gdy przemawia za tym interes społeczny". Chodzi o interes społeczny w znaczeniu generalnym, a nie o sytuację, w której udział organizacji uzasadniony jest tylko jej interesem „[...] Gdy przemawia za tym interes społeczny". Zatem żądanie wszczęcia postępowania administracyjnego czy dopuszczenia organizacji do udziału w postępowaniu nie powinno być ograniczane tylko do interesu samej organizacji społecznej, lecz powinno służyć ochronie wartości wspólnych dla większej liczby podmiotów. Wartościami tymi mogą być przykładowo ochrona życia i zdrowia mieszkańców, poprawa warunków bezpieczeństwa na danym terenie ${ }^{2}$.

Warto dodać, że w literaturze pojawiają się także stwierdzenia, że „interes społeczny jest odpowiednikiem pojęcia interes państwowy czy interes publiczny"3.

Ponadto „o tym, że dopuszczenie do udziału w postępowaniu na podstawie art. $31 \S 1$ pkt 2 k.p.a. jest zgodne $\mathrm{z}$ interesem społecznym, świadczyć może autentyczne i bezinteresowne zaangażowanie w ochronę interesów społecznych, w uzasadnionych racjonalnie sytuacjach, kiedy rzeczywiście można mieć poważne obawy co do zagrożenia określonych wartości, wśród których można wskazać ochronę przyrody" . Moim zdaniem wykluczone jest domaganie się wyłącznie od organizacji udo-

1 Dz.U. z 2013 r., poz. 267 ze zm., tj.; dalej: k.p.a.

2 Zob. wyrok WSA w Poznaniu z dnia 23 października 2013 r., IV SA/Po 469/13.

3 K. Płonka-Bielenin, Zakres pojęcia ,interes publiczny” a organizacje pożytku publicznego, „Administracja” 2007, Nr 4, s. 145-170.

4 Zob. wyrok WSA w Poznaniu z dnia 10 kwietnia 2013 r., IV SA/Po 90/13. 
wodnienia przesłanki istnienia interesu społecznego, jak to miało miejsce na etapie postępowania administracyjnego $\mathrm{w}$ sprawie będącej przedmiotem głosowanego orzeczenia. Organizacja powinna przedstawić oczywiście argumenty uzasadniające dopuszczenie jej do udziału w postępowaniu albo wszczęcie postępowania. Jednak to również organ powinien dokonać weryfikacji czy przedstawiona przez organizację argumentacja uzasadnia dopuszczenie jej do udziału w postępowaniu. Przy czym nie oznacza to jednak, że „ocena taka może być częściowa, dowolna i arbitralna"5.

Rację zatem miał Sąd w niniejszej sprawie, że „ocena wystąpienia interesu społecznego musi być przedmiotem tak badania organów administracji w zakresie dopuszczenia organizacji społecznej do udziału w postępowaniu, jak również sama organizacja musi wykazać wystąpienie tej przesłanki”.

Podobny pogląd odnośnie czynnego uczestnictwa także organów w zakresie ustalania istnienia interesu społecznego znany jest też w literaturze. P. Brzozowski ${ }^{6}$ wskazuje, że „oceniając [...] wniosek organizacji społecznej o wszczęcie postępowania organ powinien zbadać nie to, czy postępowanie takie może się zakończyć pozytywną decyzją dla organizacji, ale wyłącznie to, czy samo wszczęcie postępowania jest uzasadnione celami statutowymi tej organizacji i czy przemawia za tym interes społeczny. Tylko te dwie przesłanki muszą zostać spełnione łącznie, aby wniosek organizacji można było uznać za zasadny. [...] Skoro [...] organizacja społeczna wykazała, że wniosek uzasadniony jest celami statutowymi tej organizacji, to organy powinny były przystąpić wyłącznie do kolejnego etapu oceny, tj. zbadania, czy za wszczęciem postępowania przemawia interes społeczny". Jednak z całą mocą trzeba podkreślić, że ustalenie istnienia interesu społecznego nie podlega dowolnemu uznaniu organów.

W ramach drugiego ze wskazanych problemów wynikających z glosowanego orzeczenia należałoby zastanowić się czy zmiany w otoczeniu, w tym w krajobrazie uznać należy jako

5 Zob. wyrok WSA w Warszawie z dnia 31 maja 2011 r., II SA/Wa 403/11.

6 P. Brzozowski, Glosa do wyroku WSA z dnia 24 kwietnia 2009 r., I SA/Wa 1693/08, „Glosa” 2010, Nr 3, s. 119-123. 
działania mieszczące się w ramach pojęcia interesu społecznego wymagającego ochrony przez właściwe organizacje.

O ile w niniejszej sprawie, co słusznie zauważył Sąd, strona skarżąca nie wykazała, że spowodowanie nieodwracalnych zmian w otoczeniu poprzez nieprawidłowe zabudowanie obszaru na podstawie decyzji i warunkach zabudowy naruszy interes społeczny, to uznać należy, że walory krajobrazowe mogą być elementem chronionego interesu społecznego. W szczególności w takich sprawach wykazać należy, że ustalone warunki zabudowy nie mogą być zaakceptowane z powodu interesu społecznego albo też $\mathrm{w}$ jakim zakresie interes społeczny byłby naruszony w kontekście pogorszenia walorów krajobrazowych. Przywołane argumenty odnośnie do ochrony walorów krajobrazowych powinny wyraźnie odnosić się do interesów określonej grupy osób czy społeczności lokalnej. Przy czym argumenty te nie powinny opierać się tylko na ogólnych stwierdzeniach, ale powinny być sprecyzowane w kontekście istnienia konkretnych zagrożeń dla krajobrazu powodowanych przez realizację danego przedsięwzięcia. Należy wskazać, że z samego faktu zasad ochrony obszarów cennych pod względem krajobrazowym, na terenie których znajdują się tereny zasługujące na ochronę ze względu na wartości przyrodnicze i walory krajobrazowe, nie można wyprowadzić generalnego zakazu wprowadzania jakiejkolwiek inwestycji. Zakazy takie bądź ograniczenia wynikać muszą z innych przepisów ${ }^{7}$. Jednak nic nie stoi na przeszkodzie, by walory krajobrazowe stanowiły uosobienie interesu społecznego.

\section{Kontakt e-mail:}

karolinaszuma@gmail.com 